Accepted

20. 07. 2020

Revised

20. 08. 2020

Published

29. 10.2020
Keywords community health nurse, primary care, aging population, concession, legal regulation.

\section{Community Health NuRSING IN SLOVENIA AND CROATIA - SELECTEd LEgal Aspects}

\author{
SUZANA KRALJIĆ ${ }^{1} \&$ BLANKA KAČER ${ }^{2}$ \\ ${ }^{1}$ University of Maribor, Faculty of Law, Maribor, Slovenia. \\ E-mail: suzana.kraljic@um.si \\ ${ }^{2}$ University of Split, Faculty of Law, Split, Croatia. \\ E-mail: blanka.kacer@pravst.hr \\ CORRESPONDING AUTHOR \\ suzana.kraljic@um.si
}

\begin{abstract}
This article is dedicated to community health nursing which today constitutes the indispensable cornerstone of Slovenian and Croatian primary health-care. Authors also stress that community health nursing is recognized of crucial importance for public health and various vulnerable groups (e.g., children, elderly, ...) in many other European as well as non-European states. In Chapter 2, the authors represent basic historical milestones in both countries, Slovenia and Croatia, which have common historical roots. In Chapters 3 and 4, the central part of the article, authors analyze the current legal regulation related to community health nursing and thereby give special attention to differences in both national legal regulations. The major difference is given in concessions. Namely in Slovenia, community health nursing can be performed also based on a granted concession, but not in Croatia. In Chapter 5, some legal views on the role of community health nursing in local communities are emphasized (e.g., domestic violence). The last chapter is dedicated to the summarization of the authors' conclusions, in which they especially stress that the community health nursing in both countries today represents an important key factor for ensuring the constitutional right to health-care.
\end{abstract}




\section{$1 \quad$ Introduction}

The world's population is growing rapidly, generating complex and difficult changes in the world's society and local communities. The aging population, ever-changing disease patterns, increases in chronic illnesses, poverty, etc. have expanded opportunities for the enlargement of community-based care. Community health care represents an alternative mode of health-care delivery, as it allows for the implementation of the promotion of health and access to care by more effectively addressing the health-care needs of people where they live and work (WHO, 2010: 3). As community health nursing (synonyms are 'community nursing' and 'public health nursing') is performed both at home and in local communities, its relevance as a form of de-institutionalized nursing of certain vulnerable groups of population (e.g. especially elderly (Hlebec, Mali \& Filipovič Hrast, 2014) and lonely people) is of great importance for the quality of living in a local community.

Aware of the importance of community health nursing, WHO defines community health nursing as:

\section{"A special field of nursing that combines the skills of nursing, public bealth and some phases of social assistance and functions as part of the total public health program for the promotion of health, the improvement of the conditions in the social and physical environment, rehabilitation of illness and disability."(WHO, 2017: $5)$.}

It is difficult to imagine the primary health services without community health nursing, as it represents an indispensable cornerstone of primary health-care. So integral are they to modern public health systems that currently many countries have community-based health programs. Such programs exist, for example, in Armenia, Austria, Bosnia and Herzegovina, Bulgaria, Cyprus, the Czech Republic, Denmark (Østergaard \& Wagner, 2014), Estonia, Finland, France, Germany, Greece, Iceland, Ireland, Poland, Portugal, Romania, the Russian Federation, Serbia, Switzerland, the North Macedonia (Doncho et al., 1989), Ukraine, United Kingdom (Büscher, Sivertsen \& White, 2010) and in Japan (Japanese Nursing Association, 2016). In the future, as the world population ages, we can expect their role to expand further (Kraljić, 2014b: 78), which will result in an ever-increasing number of persons using community health nursing. Elderly people, for example, are prone to degenerative 
and other chronic diseases as well as to new other illnesses brought about by social and economic factors such as occupational hazards, accidents, and environmental poisonings caused by air pollution, noise and contaminated water (WHO, 2010: 1) and now especially by COVID-19.

\section{A brief history of community health nursing in Slovenia and Croatia}

Community health nurse is translated in Slovenian and Croatian as 'patrona:̌na medicinska sestra'. This term derives from the Latin word 'patronus', which means protector, patron, advocate (Županić, 2013: 6).

The term 'public health nurse' was first coined by Lillian Wald, who used it to define a new role for nurses who visited the sick, poor people at their homes (BuhlerWilkerson, 1993). In 1893, Wald and Mary Brewster established public health nursing in New York City's Lower East Side of Manhattan to help poor European immigrants. In 1895 they renamed it the Henry Street Settlement. The major focus was devoted to child and public health nursing (Bergren, 2017). In 1923, the nurses from Henry Street Settlement made over 37.000 home visits and cared for over 50.000 patients (Keeling, 2015). Wald believed that the purpose of nursing is not only to care for the ill but also to help improve their living and socio-economic conditions along with their ability to hold gainful employment (Kalauz, Klanjčić \& Kurtović, 2013: 562).

\section{$2.1 \quad$ Slovenia}

Wald's transformative views on community health nursing can be found in Slovenia, where community health nursing has a 100-year tradition. The first decree on the placement of a community nurse (Ger. Fürsorgeschwester, hereinafter: nurse) was passed on January 27, 1919. Angela Boškin, who was educated in Vienna, was the first Slovene to obtain a nurse placement. Thus, Boškin was the first Slovenian nurse, the first community nurse, and the first social worker. 1956 was a pivotal year. The Yugoslavia legislator enacted the Health Care Centres Act, pursuant to which community centres were established. In 1958, the European Congress in Helsinki formed sustainable directives on the functioning of community care. Dr. Andrija Štampar, who participated in this Congress, brought these directives to Yugoslavia at that time (Vuga, 1975a; Kersič, 2008; Masic, 2014; Kalauz, Orlić-Šumić \& 
Šimunec, 2008: 300; Bandur 2016; L.B., n.d: 126). He described nurses who receive both a high quality and polyvalent education as critical pillars to the development and establishment of outpatient and visiting nurse services. Dr. Štampar stressed that without properly trained nurses innovative, modern health care and health protection would be impossible (Kalauz, Klajnčić \& Kurtović, 2013: 562).

1962 was the next pivotal year in the field of community nursing. That year witnessed the adoption of the first professional instructions on the organization and functioning of community nursing. These instructions contained a definition, purpose, tasks, and goals of community nursing. In 1971, the community nurses of Slovenia, with the help of the Association of Nurses of Yugoslavia, published the »Elaborate of Community Nursing Service«. The fundamental goal of the Elaborate was to conjoin the tasks of a midwife, a social worker and health care at home into community health nursing so as to better serve the varied needs of families. All of the aforementioned tasks should be performed by a polyvalent-trained nurse, capable of managing a large array of patients in a family without regard to age, sex, nationality, or disease. The polyvalent form of community health nursing is holistic and respects the health, social, physical, and sociological specialties in periods not only of health but also in disease. Its opposite is the monovalent form of nursing, the hallmark of which is work in a singular field of community health nursing, managing one kind of patient irrespective of age or disease (Kersič, 2008; Razinger, 1991; Vuga, 1975b).

\subsection{Croatia}

In Croatia, community health nursing has a rich tradition dating back to 1921. In that year, the first school for health nursing for tuberculosis patients and infants was founded in Zagreb. Dr. Vladimir Ćepulić was the director of this school. The first students were eight laywomen and 30 nuns from the orders of St. Vincent and St. Cross (Kalauz, Orlić-Šumić \& Šimunec, 2008: 299). In 1930, the Centre for Social and Hygienic Work was established in Zagreb. Beginning in 1933, Croatian community nurses assumed the role of the first social workers in Croatia. Starting in 1935, they took on the role of educators by holding courses for mothers and babies and home care. Starting in 1952, they worked with doctors in health centres, which were at that time territorially determined. However, starting in 1993 Croatian residents were given a free choice of doctors. Despite this change, in order to 
preserve the patronage activity, which is related to the territorial division, the nurses were separated from medical teams and united in a special patronage service of the health centres. Private in-home health care facilities were established beginning in 1997 (Kanisek, Barać \& Voloder, 2016: 57-58).

\section{Legal placement of community health nursing in the Slovenian and Croatian legal systems}

\subsection{Slovenia}

Although community nursing is not explicitly mentioned in the 'Constitution of the Republic of Slovenia' (hereinafter: CRS), nevertheless a constitutional basis for it may be found in Art. 51, Par. 1 CRS which provides everyone with the right to health care under the conditions provided by the law. Apart from the constitutional provision, every Slovene resident meeting the conditions also has the right to community nursing services as such services represent a constituent component of health services on the primary level in line with the 'Health Services Act' (hereinafter: HSA). Namely, Art. 7 of the HAS provides that the basic health service (among others) also encompasses nursing visits at home. Further, Art. 9, Par. 1 also stipulates that a health care centre is a health institution and accordingly (among others) is obligated to maintain organized community nursing.

The legal basis of community health nursing in Slovenia is set forth in the 'Rules on compulsory health insurance.' Art. 26(7) thereof provides that the rights of insured persons to basic health services encompass (among others) community health nursing. The broadest framework for providing qualitative preventive nursing for the inhabitants treated in community care is set by the 'Rules on carrying out preventive bealth care at the primary level' (hereinafter: Rules on carrying). Nursing for inhabitants, who are treated in community health nursing, is addressed in the expansive chapter 7. Another important document regarding nursing is the Strategy of development of nursing and bealth care in the Republic of Slovenia for the period from 2011 to 2020. This document defines the key activities for the field of health care within community health nursing. 


\subsection{Croatia}

As in Slovenia, the Constitution of the Republic of Croatia (hereinafter: CRC) does not expressly mention community nursing. Nevertheless, a constitutional basis for this "right" may be taken from a combined interpretation of Art. 21 (the right to life), Art. 70 (the right to healthy life) and Art. 59 (the right of everybody to health care under the conditions provided by the law).

In Croatia, nursing in general, is governed by the Nursing Act (hereinafter: NA) and community nursing specifically by the Croatian Health Care Act (Art. 30, Art. 103, etc.) as the part of the primary level of the health care. The general conditions of the contract on the implementation of the primary health care from the compulsory health is also of critical importance (Art. 31-32). Part 1.6 of The Plan and Program of Measures for the Activity of Community Health Care is also relevant as it defines the key activities of community health nursing.

\section{$4 \quad$ Implementation and organization of community health nursing}

\subsection{General}

The importance of community health nursing is also recognized by the WHO. For example, its regional office for Europe in 2000 adopted the Munich Declaration: Nurses and Midwives: A Force for Health (hereinafter: Munich Declaration). The Munich Declaration urges all relevant authorities in WHO's European Region to accelerate their action to strengthen nursing and midwifery by (for the paper relevant):

a) seeking opportunities to establish and support family-focused community nursing and midwifery programs and services, including, where appropriate, the family health nurse;

b) enhancing the roles of nurses and midwives in public health, health promotion, and community development.

The newer document, promoting the importance of community nursing, was adopted in 2015: 'Nurses and Midwives: A Vital Resource for Health European compendium of good practices in nursing and midwifery towards Health 2020 goals'. This document stresses the importance of engaging citizens in the community to be personally involved in 
community-based nursing and midwifery services to thereby garner ownership of health issues. The aims are to promote healthy living among people and families, to provide early interventions to support independence and well-being in older populations, and to promote efficient and quality home care. These practice developments should be implemented through integrated service models and facilitated via ICT-supported communication with local communities (WHO, 2015: 9).

\subsection{Slovenia and Croatia - similar or different?}

The community health nursing is a special form of health care providing active health and social care for individuals, families, and communities (Šuštaršič et al., 2006: 248). Departing from Art. 5, Par. 1 of Slovenian HSA, on the primary level the network of public health services is determined by the community or municipality. The Slovene health care system is relatively centralized and the responsibility of local communities is still limited. The local communities conduct only those tasks and activities that were previously assigned to them from the central level (Albreht et al., 2009: 31). Therefore, community health nursing today in Slovenia represents an important pillar of primary health services as an organizational unit of basic nursing in health care centres, at patients' homes, in social care institutions, and in local communities.

Departing from Croatian Arts. 30 and 103 HCA, on the primary level the network of public health service is determined by the community or municipality. It is funded by the 'Croatian Institute for Health Insurance' (Hrvatski zavod za zdravstveno osiguranje - hereinafter: HZZO), which prescribes standards and programs. Working hours in all locations are in the morning and are divided into two parts. The first part is spent by the nurse in the ambulance, in the patronage room. During this period the nurse is available for telephone contacts and appointments before going out to the places where people live. Preventive controls and advice for users who come either of their own accord or are sent by a doctor are also carried out in the community nurse's room. The visits can also be at the behest of other family members or neighbors. According to the HZZO program, the community nurses are also authorized to come uninvited to places where people live, to find and monitor a particular vulnerable population (Stanković, n.d.). 
In Slovenia the graduate nurse is responsible for providing community health nursing services. As a smaller, sub-component of overall health-care, the labour normative in the field of community nursing comprises approximately 2.500 inhabitants. A community health nurse may conduct health care in the framework either of her/his employment in a public health care centre or as an independent business based on a concession. But, even in case of a concession, the community health nurse is included in the public health network. The concessionaire has to cover all fields of community care, i.e.: health-social treatment of an individual, a family and a community, health care of a pregnant woman, young mother and the newborn at home and nursing and care for patients at home (Železnik et al., 2011: 5). A concessionaire has to provide for community health nursing 24 hours a day all year (Zavrl Džanović, 2007: 2).

In Croatia, as discussed in section 3.2, community health care is provided by community nurses following the Plan and program of measures for the activity of community health care, which is part 1.6. of the Plan and program of health care measures from compulsory health insurance. The Croatian HZZO covers all costs of provided health care services. Community nursing is intended for all residents of the Republic of Croatia, regardless of whether they are sick or healthy members of the community, utilizing a holistic approach, respecting cultural and environmental factors. Each community nurse cares for an average of about 5.100 residents in a specific geographical area. The basic intervention model of the community nurse is a home visit to an individual and/or family directly where they live, in a home or at the place of current accommodation, home for the elderly and infirm, children's homes, rehabilitation centres, foster families, Association for Inclusion, etc. (Tikvić, n.d.).

As previously mentioned, starting in 1952 community nurses worked with doctors in health centres, which were territorially determined. However, beginning in 1993 Croatia introduced a new system providing residents with the freedom to choose their own doctor. In order to preserve the community nursing activity, which is related to the territorial division, the nurses were separated from medical teams and united in a special community nursing service of the health centres. (Kanišek, Barać \& Voloder, 2016: 57-58). 
Basic education for all nurses in Croatia consists first of a five-year-long high school education (Art. $7 \mathrm{NA}$ ). After that, they become trainees, until they acquire the license, which allows them to perform independent work, from the Croatian Chamber of Nurses (Art. $15 \mathrm{NA}$ ). After that, nurses optionally can complete a university undergraduate or professional undergraduate study, a university graduate study or a specialist graduate professional study (Domitrović et al., 2018; Kalauz, Orlić-Šumić \& Šimunec, 2008).

In an effort to help minimize the possibility of patient complications due to nurses' unfamiliarity with the population and the characteristics in her/his territory, a community health nurse is required to make daily, monthly, and annual work plans. Having good knowledge of the territory, the local community, and the inhabitants enables the nurse to perform her/his work as planned and in harmony. Planning (daily, monthly, annually) in Slovenia takes the following factors into consideration:

a) the number of biological or risk groups of the population: children (newborn, babies, small and pre-school children, pupils, and teenagers), women (pregnant, young mothers, women infertile and post-menopausal period), disabled, aged people, patients, violence in families, the presence of migrants or Roma or other nationalities in the local community. The nurse must be capable of recognising the influence that social factors, poverty, ethnic, religious, and cultural differences and inequalities play on various groups of the population and try to plan to account for these wide-ranging factors. Thus, the nurse must account for the most important factors influencing the health of an individual and a community: heritage, socioeconomic, lifestyle, environmental factors, sex/gender, cultural specialties, and political factors. Special attention should be given to threatened groups of the population;

b) social-medical indicators of the health status in a certain territory: a snapshot of the status in the field (municipality, region), vital statistics (birth rate, death rate, dead born), health statistics (morbidity, traumatism, absenteeism), demographic statistics (number of inhabitants, structure due to age and sex/gender);

c) hygienic-epidemiological specialties of the area: registered hygienic problems (drinking water, smog, disposal of wastewater), epidemic diseases (lice, scabies, infectious inflammation of the liver), sporadic diseases; 
d) characteristics of settlements (urban, geographic, economic, cultural);

e) experience from past years (Železnik et al., 2011).

In this way, community health nursing is a special form of health care. It has a unique mission in the sense that it is the only health service that is charged with the responsibility of recognizing health conditions of people in their local communities and developing appropriate action plans to orient such patients into the health system. Community health nurses actively manage the health status of the patients in defined areas and develop promotional health programs for this population. These programs help encourage the patients to invest and participate not only in their own health and well-being but also in family health. Certain priority groups of the population, owing to their unique biological characteristics (babies, pupils, pregnant women, elder people, etc.), their particularized living conditions and social threats (immigrants, homeless people, people threatened by poverty, etc.) as well as other health threats (disabled people and chronic patients, etc.) demand more intense individual and family treatment. Community health nursing is designed to meet the unique challenges faced by these priority groups. The relevance of the role of community health nursing is recognised also in the field of palliative care, as community nursing enables a more systematic and qualitative management of a patient's symptoms (Kraljić, 2014a; Kraljić, 2014b). The importance of community health nursing is also stressed in the 'Resolution on the National Health Care Plan 20162025' (ResNPZV 2015-2025), especially from the aspect of connection or inclusion in palliative and long-term nursing. Furthermore, developments in community health will be the key to ensuring access to quality treatment for vulnerable populations and reducing health inequalities. Consequently, the ResNPZV 20152025 in Measure 5 envisages a project of upgrading community health nursing at the primary level. 
Table: Basic statistical information about community health nursing in Slovenia and Croatia

\begin{tabular}{|r|c|c|}
\hline & Slovenia & Croatia \\
\hline population (July 2020) & $\begin{array}{c}2.078 .938 \\
\text { (Worldometers, 2020b) }\end{array}$ & $\begin{array}{c}4,105,267 \\
\text { (Worldometers, 2020a) }\end{array}$ \\
\hline $\begin{array}{r}\text { employed nurses, } \\
\text { midwives, medical } \\
\text { technicians }\end{array}$ & $\begin{array}{c}21.276 \text { - December 2018 } \\
\text { (SURS, 2020) }\end{array}$ & $\begin{array}{c}41.332 \text { (Register of the } \\
\text { HKMS) }\end{array}$ \\
\hline $\begin{array}{r}\text { community health } \\
\text { nurses }\end{array}$ & Cca. 850 & Cca. 840 \\
\hline $\begin{array}{r}\text { Community health } \\
\text { nurses with concession }\end{array}$ & Cca. 100 & 0 \\
\hline standard & 2.500 & 5.100 \\
\hline
\end{tabular}

\section{Concession in the field of community nursing - the example of Slovenia}

Slovenian local governments are responsible for regulating health services at the primary care level within their respective communities. It is the responsibility of the local community to grant concessions for private health care providers at the primary health care level (with the consent of the Ministry of Health) (Albreht et al., 2009: 68). And, for community nursing, as a part of primary health service, a concession may be conveyed, as well.

A concession is an administrative decision. It is a unilateral act performed by the state. The word concession derives from the Latin word 'concedere' and means 'to allow'. Thus, a concession may be defined as authorization conveyed by the state or local community or by a body authorized by one of them in a provided way and a prescribed form to a person of civil law, as a rule. The one authorizing the concession is called the 'grantor', and the person obtaining the concession is called 'concessionaire'. Accordingly, the grant of a concession allows the concessionaire legal authority to conduct the prescribed activity (economic or non-for-profit) of public service or management, use, or exploitation of natural goods. The concessionaire thus conducts the activity pursuant to authority vested by the exclusive competence of the state or the local community. 
A concession is established by the concession act being a conditio sine qua non for the formation of the concession relation (Kraljić, 2011; Drnovšek \& Brezovnik, 2016: 673). As the grant of a concession on the primary level of health-care is within the competence of the community, which is an administrative body, the procedure of obtaining a concession is an administrative procedure and is governed by the 'General Administrative Procedure Act (hereinafter: GAPA).

According to Art. 7 HSA, community health nursing is a constituent part of the primary level of health care. Departing from the mentioned Art. 7 HAS and consistent with Art. 3, Par. 1 HSA (and concretely also with Art. 41 HSA), healthcare (i.e. also community health nursing) based on the authorization of the Ministry of Health, may be conducted by domestic or international legal entities or natural persons if they meet the conditions set forth by HSA. Further, Art. 12 HSA stipulates that if, in a community or town, there is no health-care centre, the community or town, respectively, in cooperation with the 'Health Insurance Institute of Slovenia' (Zavod za zdravstveno zavarovanje Slovenije - hereinafter: HIIS), must make adequate provisions for the performance of preventive and other programs in general health-care through a contract either with another health-care centre, a health station or private health-care personnel conducting public health services based on a concession. A concession for the performance of public service in general health-care is conveyed by a decision filed by a municipal or town body, competent for health, with consent by the Ministry of Health. A concession for the performance of public service in other health activities is conveyed by a decision filed by the Ministry of Health.

Certain conditions have to be met in order to conduct private health care and, specifically, private community health nursing. These conditions are of both a professional and spatial-technical nature. The conditions have to be given in compliance with HSA, 'Rules on the requirements to be met by the persons engaged in private health activities' (hereinafter: Rules on the requirements), 'Rules on the Keeping of the register of private health workers' (hereinafter: Rules on the Keeping) and the 'Rules on the filing of opinions on the performance of private health-care activities in the field of health-care and midwife care and in the process of obtaining of a concession' (hereinafter: Rules on the filling) adopted by Nurses and Midwives Association of Slovenia in 2015. 
A concession for private community health nursing will be conveyed, if the following conditions are met:

a) a community health nurse is a health worker performing her/his job in immediate contact with patients and therefore has to know the Slovenian language (Level C1), and in bilingual areas, where the Italian or Hungarian minorities lives, a community health nurse must also know the language of these minorities. Establishing Slovenian language proficiency (B2) is proven by a public certificate on finalization of secondary school or a confirmation of an educational institution (Art. $63 \mathrm{HSA}$ );

b) a community health nurse must have the required higher education and be able to work independently in accordance with Art. 64 HSA;

c) a community health nurse must not already be employed, as this is a condition for the contract with Slovene HIIS. For entry into the register, a confirmation of a former employer on the termination of the employment has to be presented;

d) a community health nurse, as a conductor of nursing and midwifery, has to be entered into both the register of nursing and midwifery and the register of private conductors of nursing and midwifery of Slovenia led by the Ministry of Health (compare with Art. 35 HSA). The nurse must own a valid license;

e) the community health nurse must not have a legally final prohibition on the conducting of the vocation in the field of nursing (the confirmation must not be older than three months). This is a vocational condition;

f) a community health nurse must have at least three years of working experience in the field of nursing and midwifery;

g) a community health nurse has to be additionally capable of a narrow professional field, where the nurse wishes to conduct her/his private community nursing (comp. Art. 11 of the Rules on the filing);

h) a community health nurse must provide all required work equipment;

i) a community health nurse must obtain a positive opinion by the Nurses and Midwives Association of Slovenia. This is a vocational condition (Krajnc, 2006). 
As a request for a concession is an administrative procedure and subject to the GAPA, a decision must be made within two months from the date of filing the application (comp. with Art. 222 par. 1 GAPA). ${ }^{1}$ The community where the nurse applicant applies has the so-called right of discretion to decide by its own judgment whether to grant a concession, even if the applicant meets all conditions and obtains all necessary favourable opinions (Krajnc, 2006). In fact, community health care centres quite frequently issue negative opinions concerning applications for concessions on the basis that the community where the concession is sought already has sufficient community nursing care (Vrbnjak, 2007: 20).

On the other hand, a contract between the local community centre and the applicant may be entered into when a positive decision is reached. By entering into the concession contract, the transfer from the public into the private sector is made. As a rule, the candidate for private community service should already have worked in the area of community health nursing. In the contract, the grantor (local community) and the concessionaire (community health nurse) regulate the relationship in connection to the performance of the public service and the conditions to be met by the concessionaire for the public service. The concession contract mainly stipulates the kind of health activity to be performed (in our case the community health nursing); the range of public services to be provided; the starting date of the concession; the rights and obligations of the grantor and concessionaire during the duration and after expiration of the concession; the cancellation period of the concession; how the concession contract will be financed, etc. (comp. Arts. 44.e and 44.f HSA).

The performance of private community health nursing may begin as early as on the day the decision is made regarding the entrance into the register of private health workers. However, the work must begin no later than one year from the signing of the concession contract, at the latest (Art. 3.b HSA). If the community health nursing does not start work within the one-year limitation period from the signing of the concession contract, the community is obligated to file a new decision regarding obtaining the concession. In situations involving a concession with a doctor that will

\footnotetext{
${ }^{1}$ Art. 222 GAPA determines: »(l) ...when a procedure is started based on an application by the party or ex officio, if this is in the interest of the party, the competent body has to pass a decision and hand it to the party within two months, at the latest. ... (4) If the competent body, against whose decision the complaint is allowed, does not pass the decision and does not hand it to the party within the provided deadline, the party has the right to complaint, as if the application would have been rejected."
} 
perform private health services and who will work directly with patients, the doctor must obtain liability insurance that will cover damages sustained by patients in the case of his or her negligence. In comparison with a private doctor, under Slovenian legislation, there is no similar provision requiring compulsory liability insurance for community health nurses.

If the concessionaire fails to conduct public services in accordance with the law, or according to the decision on granting the concession, or pursuant to the terms of the concession contract itself, then the concession grantor must establish a deadline by which the concessionaire must show improvement in whatever deficiencies were identified. In case of a discrepancy between the concession decision and the concession contract, the arrangements set out in the concession decision shall apply (Art. 44.f par. 2). If the concessionaire does not remedy the deficiencies within the set period, the concession will be revoked. In the case a concession is revoked, the grantor nevertheless is obliged to take appropriate steps to accept patients into health-care at another health institution or to direct said patients to another private health worker conducting the public service, under the same conditions (Art. 44 HSA). A concession may also end simply because the expiration date as established in the contract materializes or in case of cancellation of the contract within a limitation period. Concession also ends if the concessionaire fails to perform required activities within one year after the entry into the register. The legislator enacted this provision to help ensure that concessionaires would carry out their work diligently, and thus to advance the public health. The concessionaire may also terminate the performance of a private health activity before the end of the time set forth in the contract. Termination may also occur in the case of death of the concessionaire or if a final decision prohibiting the performance of the activity or the vocation is made, so that the concessionaire ceases to meet the conditions required for the activity. Likewise, the concession ends if the activity is performed in contradiction with the entry into the register (comp. Art. 44.i HSA).

If the concessionaire is unable to perform the concession activity for more than six months continuously due to illness, care and upbringing of the child or education, the concessionaire and the grantor shall agree on the temporary performance of the concession activity for a maximum period of two years. If the concessionaire suspends the performance of the concession activity for more than two years for the mentioned reasons, the concession shall be revoked (Art. 44.g HSA). 
Under the Art. 10 of the 'Rules on the filling', the conductor of private health activity in the field of (in our case) community nursing is obliged to:

a) perform the community nursing in line with valid legislation;

b) respect valid vocational directives and protocols in nursing or midwifery and care;

c) remain current in their vocational training and education;

d) provide mentorship to students of higher education schools and departments in the field of nursing or midwifery, if they obtain the status of an educational institution;

e) permit professional supervision over her/his work;

f) perform all work in line with the Code of Ethics in Nursing and Care of Slovenia and the Code of Ethics for midwives of Slovenia;

g) provide for permanent performance of nursing and midwifery and care, if this is demanded by the nature of the work;

h) by agreement to provide for regular replacements in times of absence;

i) conscientiously fulfill all of the obligations established by the public authorisation;

j) work exclusively in the field of the vocational activity;

k) cooperate with the local community;

1) regularly inform the Nurses and Midwives Association of Slovenia on the changes of data maintained in the Register of Private Health Workers;

m) provide for a steady professional connection to professional services in the area, where he or she conducts the private health activity.

\section{Community health nursing and local communities}

Community health nurses not only help protect and preserve the health of community members but they also actively promote self-care among individuals and families. Community health nursing provides care to individuals, families, and groups wherever they live, work, play, or go to school. Therefore, community health nurses should have professional autonomy to provide ethical and legal nursing care services in community settings, such as schools, homes, and health centres (WHO, 2010). They enter into families' and patients' homes. As such, these nurses become engaged in the most intimate aspects of their patients' lives, such as their social and 
property circumstances, their living conditions, their distresses, their anxieties and fears. Therefore, is very important that community health nurses are also familiar with relevant legal provisions, so that they can assist the patient and their families in securing proper legal advice to protect their legal interests (e.g., in case of domestic violence, patient's rights, succession planning, personal data protection, etc.).

Community health nursing presents the opportunity to increase the involvement in public health and community development (Büscher, Sivertsen \& White, 2010). Today, the relevance of community health nursing and similar forms of nursing are widely recognized by the local communities. In England, for example, on the level of local communities, the so-called 'community matron' engages in the care for chronically ill patients and persons in need for long-term care. The community matron structure represents an excellent example of a creative method to integrate nurses into local communities. Community matrons meld both the values of clinical skills together with the knowledge of nurses to provide proper services to the local communities. By including the community matron into local communities, it is possible to achieve the objective of decreasing the number of unplanned hospitalizations of chronically ill patients and persons in need for long-term care (Drennan et al., 2011). England also utilizes the so-called 'parish nursing,' which has a very long heritage in light of the fact that in the past church communities were one of the key providers of health care. Wordsworth, Moore \& Woodhause (2016) observe important differences between community and parish nursing. Community health nursing concentrates mainly on patients with complex health needs. Due to this, in their opinion, community health nursing is less flexible, or stated differently, less adaptable than parish nursing. Namely, a positive characteristic of parish nursing is the extra-ordinary flexibility that it offers, as it may be conducted at home, in a church, in the community, and also may be designed regarding the needs of the community. This is of special relevance as it relates to preventive or supporting nursing care and the maintenance of the health and well-being of individuals, family, and community. 
Since both Slovenia (median age is 44.5 years) and Croatia (median age is 44.3 years) ${ }^{2}$ are faced with aging populations (so-called 'greying the globe') (Kraljić, 2014b: 78), both are already observing an increase of users of community health nursing services. Namely, people, due to age and chronic diseases, need the help of other people (e.g., long-term care) as well as in the terminal phase of their lives (e.g., palliative care ${ }^{3}$. Community health nursing has the benefit of allowing services to be performed at the patient's home and within the local community, thereby enabling the patient to remain in the comfort of their home longer, sometimes even to the end of their life, together with their closest family and friends. The aging of the population and long-term care has a key role in the short-term, mid-term, and long-term planning of health care not only for individuals but for the whole of society. The aging of the population has led to an increase in the number of people in need of health care assistance. Significantly, however, many people suffering from chronic diseases and long-term health problems do not always require hospitalization, or at least not long-term hospitalization (they do often require shortterm hospitalization for acute problems, which are managed, and then the patient is discharged). Accordingly, community health nursing and the care for patients connected to it in a local community or/and at her/his home represents an imperative of the present time (Cindrić et al., 2015: 244) and especially for the future. The community nurse must act as a conduit between institutional care (health, education, child's care, social care) and individuals or families, and communities.

Community health nurses manage the health care of patients in particular geographical areas. Since community health nurses care for patients at their home and within the local community, these nurses actively manage their patients' health status in a particular health (geographical) area and develops programs to aid in the promotion of health, thereby encouraging the patients to invest in their own health and the health of the families. Some nurses with specialized skills and interests request that they provide care and management to priority groups of the population

\footnotetext{
${ }^{2}$ Population and median age of selected countries: a) China as the country with highest population (1.439.323.776) has median age of 38.4 ; b) The median age in Japan is 48.4 years by the current population of $126,473,774$; c) Italy has with 47.3 years the highest median age in Europe (population is $60,461,826$ ); d) the population of Uganda is $45,741,007$ and its median age is 16.7 years; e) Niger has the lowest median age (15.2). Data obtained by Worldometers, 2020c.

${ }^{3}$ There is the 'National plan for the development of palliative care in the Republic of Croatia 2017-2020', which emphasizes the important role of community health nurses in the palliative care system. In Croatia, there are public and private Homes for elderly and infirm. In public homes there is a very long waiting list, sometimes even 10 years, and private homes are expensive. It is possible that the social welfare center decides that the community pays for that person.
} 
due to their biological characteristics (babies, pupils, pregnant women, elder people, etc.), due to the changed living conditions and social threats (immigrants, homeless people, etc.) as well as health threats (disabled persons and chronic patients, etc.) among other things (chapter 7 Rules on carrying).

It is of paramount importance for the community health nurse to have knowledge of the characteristics of the local community and of its population, as well as the most important factors influencing the health of the individuals living within that local community. Community health nursing works on five levels of health care (Šušteršič et al, 2006): preservation and strengthening of health, prevention of sickness, detection of sickness, treatment of sickness, rehabilitation after injuries and diseases (Grubar, 2013: 29). Community health nursing, being so closely connected with the local communities they serve, has the distinct advantage of being able to promptly detect social changes and to nimbly find suitable methods to quickly and effectively respond to them (Skupina Patronaža, 2015).

Community health nurses work to help prevent diseases and illnesses and to promote the general well-being of the people in the local communities they serve by employing a variety of techniques including: lecturing, learning workshops, cooperating with local media and sports, cultural and groups and charitable organizations (e.g., the Red Cross), leading self-help groups, among other things. Community health nurses can forge special connections with the local community, especially in large, sparsely populated areas and where the population is geographically widespread (e.g., in mountain areas). In such areas (which in most countries comprise large portions of the population) people typically live long distances from health institutions and usually seek health-care less frequently. These populations, in particular, frequently turn to community health nurses for help in case of health crises (as is the case currently with the Covid-19 pandemic).

Community health nurses interact with their patients, families and the community throughout all of their life-cycles and situations. That is to say, these nurses interconnect with their patients both in times of full health and economic well-being and in times of sickness, injury, incapacity and socio-economic crisis (Skupina Patronaža, 2015). This fact often subjects community health nurses to a whole host of ethical and legal dilemmas (e.g., refusal of help from the side of the patient, violence in a family, aggression of patients and/or relatives, among other things). 
This underscores the importance of the community health nurse being tightly connected and integrated into the environment where employed. As reflected in the table set forth earlier in this paper, the work normative in Slovenia is 2.500 inhabitants per community health nurse and in Croatia is 5.100 inhabitants per community health nurse. In both countries, those are large cohorts. From these statistical realities, we may conclude that the community health nurse forms a vital part of the fabric of the local community and must stay abreast of the every-day functioning of life within the local community being served. During the visits to the local communities and the patients at their homes, the community health nurse confronts the realities of many harsh situations impacting the families being served. These include, on an individual level, such matters as divorce, childbirth, family violence; loneliness of elderly people, bad living circumstances; and, at the local level the situation of families in the local community, their relations towards the neighbours, etc. In the course of the nurse's work, she/he may well become acquainted with irregularities in the families being served, such as family violence, alcoholism, etc. Therefore, the field of family violence is certainly one of the key areas of cooperation between the local community and the community health nurse. In accordance with the 'Domestic Violence Act' (hereinafter: DVA), local communities have a legal responsibility to implement all procedures and measures needed to protect victims from threats, to protect their best interests and to otherwise help insure respect for the victim's integrity. If the victim of violence is a child, the child's best interests and rights assume priority over other participants involved in the procedures (Art. $5 \mathrm{DVA}$ ). Community health nurses also have the responsibility to report any incidences of abuse or violence that they learn of to the social work centre (Art. 6 DVA). All information gained through work has to remain confidential as a professional secret. Art. 6, par. 2 DVA stipulates an exception to the rule of confidentiality and expressly refers to health workers and consequently community health nurses. They are legally required to immediately inform the social work centre, the police or the prosecutor, when they have a suspicion that a child or a person incapable of taking care of himself or herself for personal circumstances, is a victim of violence. A similar provision providing for an exception to the usual rule protecting professional secrets can be found in Art. 45 of Slovene 'Patient Rights Act' and in Art. 142 par. 2 Slovene 'Penal Code'. The relevance of the topic of family violence is additionally strengthened by the 'Rules on procedures for dealing with domestic violence in the implementation of health activities (hereinafter: Rules on handling) that provide that health workers who conduct health activities in community nursing are 
obligated to participate in education on family violence (art. 8 par. 1 line 2 Rules on handling).

\section{$7 \quad$ Conclusion}

Presently in both Slovenia and Croatia, community health nursing, as a constituent element of health care, and as a right based on compulsory health insurance, represents an essential cornerstone to the realization of the right to qualitative health care. The two countries diverge, however, in that while Slovenia has concessions Croatia does not. However, starting in 1997 private in-home health care facilities have been permitted. The basic advantage of community health nursing is the possibility of managing the patient's care at the patient's home and within the local community. There are numerous advantages gained when the patient receives health management in the environment where the patient lives and is closely connected. There is a saying that there is security in familiarity. Community health nursing helps to provide this security by managing the patient's health care needs in the familiar setting of the patient's home where family and friends are nearby. This localized treatment lends itself to safety, trust, tranquillity, and connectivity to people and things. Local communities in Slovenia and Croatia recognized the importance of community health nursing and have developed systems of cooperation between community health nurses and local communities. For example, community health nurses are connected to kindergartens, schools, charitable organizations, among other things. They have permission to go into the places where people live even if not invited, they cooperate with social workers, doctors, etc. They provide substantial benefits to the health system and for the people and local communities. They help ease the burden on over-worked traditional medical facilities. As discussed, they can be of particular benefit in rural areas, where the population (often of aged people who cannot drive and are immobile) are at great distances from urban centres.

We can conclude that in Slovenia and Croatia it is necessary to continue to ensure the quality of community health nursing, which is an important constituent element in ensuring quality health-care and patients' protection, thus helping to ensure that patients' right to health and quality health-care is fulfilled. Indeed, from a policy standpoint efforts should be made to further encourage the use of community health nursing. So as to be able to best provide their essential services, in addition to having 
a proper nursing education, community health nurses should also have an understanding not only of the basic legal principles of human and patients' rights, health, and family law but also of personal data protection and professional secrecy. Based on the fact that the populations in both Slovenia and Croatia are among the oldest in the world in terms of median age, and that both countries face a deficit of institutional care and care for the elderly, community health nursing can be particularly important in ensuring the right to health care to these vulnerable populations of elderly people, and in particular their rights to dignity, privacy and family life.

\section{References}

Albreht T. et al. (2009) Health Systems in Transition - Slovenia, Slovenia: Health system review, 11(3), pp. $1-168$.

Bandur, S. (2016) Angela Boškin je bila slovenska Florence Nightingale, Delo, 3.3.2016, retrieved from: http://www.delo.si/prosti-cas/zanimivosti/angela-boskin-je-bila-slovenska-florencenightingale.html (13 July 2020).

Bergren, M.D. (September 30, 2017) School Nursing and Population Health: Past, Present, and Future, OJIN: The Online Journal of Issues in Nursing, 22(3), Manuscript 3, retrieved from: https://ojin.nursingworld.org/MainMenuCategories/ANAMarketplace/ANAPeriodicals/OJ IN/TableofContents/Vol-22-2017/No3-Sep-2017/School-Nursing-Population-Health.html (20 July 2020).

Buhler-Wilkerson, K. (1993) Public health then and now - bringing care to the people: Lillian Wald's Legacy to Public Health Nursing, American Journal of Public Health, 83(12), pp. 1778-1786, doi: 10.2105/ajph.83.12.1778.

Büscher, A., Sivertsen, B. \& White, J. (2010) A force for health - Survey on the situation of nursing and midwifery in the Member - States of the European Region of the World Health Organization 2009 (Copenhagen: WHO Regional Office for Europe).

Cindrić, Ž., Cazin, K., Volkmer Starešina R., Pišćenec I. \& Letić A. (2015) Otvaranje samostalne sestrinske djelatnosti, Sestrinski glasnik; 20(3), pp. 244-249.

Domitrović, D. L., Relić, D., Britvić, A., Ožvačić Adžić, Z., Jureša, V. \& Cerovečki, V. (2018) Obrazovanje medicinskih sestara u Republici Hrvatskoj, Liječnički vjesnik, 140(7-8), pp. 229236.

Doncho, D., Spasovski, M., Kosevska, E. \& Pejkovski, V. (1989) Patronage Nurse and Health Education, retrieved from: https://www.researchgate.net/publication/271432879_POLYVALENT_PATRONAGE_N URSE_AND_HEALTH_EDUCATION (11 July 2020).

Drennan, V. et al. (2011) Establishing new nursing roles: a case study of the English community matron initiative, Journal of clinical nursing, 20(19-20), pp. 2948-2957, doi: 10.1111/j.13652702.2010.03643.x

Drnovšek, K. \& Brezovnik, B. (2016) Public services concession in Slovenian legislation, Lex localis Journal of Local Self Government, 14(3), pp. 671-694.

Grubar, D. (2013) Zahtevnost zdravstvene nege v patronažnem varstvu, v: Podhostnik Ana (ur.). 5. dnevi Marije Tomšic - Napake v zdravstveni negi: zbornike prispevkeov (Novo mesto: Visoka šola za zdravstvo), p. 28.

Hlebec, V., Mali, J. \& Hrast Filipovič, M. (2014) Community care for older people in Slovenia, Antropological Notebooks, 20(1), pp. 5-20. 
Japanese Nursing Association (2016) Nursing in Japan (Tokyo: Department of International Affairs), retrieved from: http://www.nurse.or.jp/jna/english/pdf/nursing-in-japan2016.pdf (10 July 2020).

Kalauz, S., Orlić-Šumić, M. \& Šimunec, D. (2008) Nursing in Croatia: Past, Present, and Future, Croatian Medical Journal, 49(3), pp. 298-306, doi: 10.3325/cmj.2008.3.298.

Kalauz, S., Klanjčić M. \& Kurtović, B. (2013) Ethical aspects in community nursing in Croatia, Periodicum Biologorum, 115(4), pp. 561-566.

Kanisek, S., Barać, I. \& Voloder, V. (2016) Patronaža- jučer, danas, sutra, Hrvatski časopis za javno zdravstvo, 12(45), pp. 57-58.

Keeling, A. (2015) Historical Perspectives on an Expanded Role for Nursing. OJIN: The Online Journal of Issues in Nursing, 20(2), Manuscript 2, retrieved from: http://www.nursingworld.org/MainMenuCategories/ANAMarketplace/ANAPeriodicals/O JIN/TableofContents/Vol-20-2015/No2-May-2015/Historical-Perspectives-ExpandedRole-Nursing.html. (28 July 2020).

Keršič, I. (2008) Od skrbstvene sestre do skrbstvene patronažne medicinske sestre, in: Horvat, M., Gorjan, R. \& Jošar, D. (eds.) Urgentna stanja v patronažnem varstvu - z̧bornik prispevkov (Murska Sobota: Zbornica zdravstvene in babiške nege Slovenije - Zveza strokovnih društev, medicinskih sester, babic in zdravstvenih tehnikov Slovenije: Sekcija medicinskih sester in zdravstvenih tehnikov v patronažni dejavnosti), pp. 7-14.

Krajnc, S. (2006) Pot do koncesije za zasebno patronažno dejavnost, referat predstavljen na 2. srečanju Združenja zasebnih patronažnih medicinskih sester, Ormož, 8. junij 2006, retrieved from: www.patronaza.si/public/images/documenti/Potdokoncesije.doc (5 July 2020).

Kraljić, S. (2011) Koncesije na področju patronažne dejavnosti, In: Pravni aspekti na koncesiite vo zdravstvoto vo Slovenija i Makedonija: 2009-2011: (završen izveštaj za rezultati od istražuvanje) (Skopje: Praven fakultet "Justinijan Prvi), pp. 111-128.

Kraljić, S. (2014a) Paliativna oskrba kot temeljna človekova pravica, In: Pajnkihar, M. (ur.) Zbornike predavanj, Mednarodna konferenca "Z znanjem do zdravja in razuoja v 21. stoletju", Maribor, 19. 6. 2014 (Maribor: Fakulteta za zdravstvene vede), pp. 42-48.

Kraljić, S. (2014b) Varstvo pacientovih pravic v okviru paliativne zdravstvene nege in oskrbe, In: Hozjan, J. (ur.). Paliativna zdravstvena nega in oskerba v socialnovarstvenih zavodib: zbornik predavanj, Zbornica zdravstvene nege Slovenije - Zveza društev medicinskih sester, babic in zdravstvenih tehnikov Slovenije, Strokovna sekcija medicinskih sester in zdravstvenih tehnikov v socialnih zavodih, 33. strokovno srečanje, Lendava, 15. in 16. april 2014 (Ljubljana: Strokovna sekcija medicinskih sester in zdravstvenih tehnikov v socialnih zavodih), pp. 77-98.

L.B. (n.d.) Naša prva medicinska sestra Angela Boškinova, retrieved from: http:/ /www.obzornikzdravstvenenege.si/1969.03.3.123 (7 July 2020).

Masic, I. et al. (2014) Public Health Aspects of the Family Medicine Concepts in South Eastern Europe, Mater Sociomed, 26(4): pp. 277-286, doi: 10.5455/msm.2014.26.277-286.

Østergaard, B. \& Wagner L. (2014) The Development of Family Nursing in Denmark: Current Status and Future Perspectives, Journal of Family Nursing, 20(4), pp. 487-500, doi: $10.1177 / 1074840714557780$.

Razinger, V. (1993) Analiza polivalentne patronažne službe v letu 1991 v Sloveniji, Obzornik zdravstvene nege, 27(1/2), pp. 53-59.

Republika Hrvatska - Ministarstvo zdravstvu (2017) Nacionalni plan programa razvoja palijativne skrbi u Republici Hrvatski 2017.-2020 (Zagreb), retrieved from: https://zdravlje.gov.hr/UserDocsImages/2018\%20Programi\%20i\%20projekti/NP\%20RAZ VOJA\%20PALIJATIVNE\%20SKRBI\%20RH\%202017-2020-

\%20usvojen\%2018.10.2017..pdf (3 July 2020).

Skupina Patronaža (2015) Prenovljena metodološka navodila za namen zbiranja podatkov o patronažni dejavnosti (Ljubljana: NIJZ), retrieved from: https://www.google.si/webhp?sourceid=chromeinstant\&ion $=1 \&$ espv $=2 \&$ ie $=$ UTF-

$8 \# \mathrm{q}=$ Prenovljena + metodolo $\% \mathrm{C} 5 \% \mathrm{~A} 1 \mathrm{ka}+$ navodila $+\mathrm{za}+$ namen + zbiranja + podatkov $+\mathrm{o}+$ patr ona $\%$ C5\%BEni+dejavnosti (4 May 2020). 
Stanković, A. (n.d.) Patronažna sestra danas, Narodni zdravstveni list, retrieved from: http://www.zzjzpgz.hr/nzl/20/sestra.htm (2 July 2020).

SURS (2020) 7. april - svetovni dan zdravja, leto 2020 pa mednarodno leto medicinskih sester, zdravstvenih tehnikov in babic, retrieved from: https://www.stat.si/StatWeb/News/Index/8761 (5 June 2020).

Šušteršič, O., Horvat, M., Cibic, D., Peternelj, A. \& Brložnik M. (2006) Patronažno varstvo in patronažna zdravstvena nega - nadgradnja in prilagajanje novim izzivom, Obzornik zdravstvene nege, 40(4), pp. 247-252.

Tikvić, M. (n.d.) Patronažna zdravstvena zaštita, retrieved from: https://dzz-istok.hr/primarnazdravstvena-zastita/patronazna-zdravstvena-zastita/ (2 July 2020).

Vrbnjak, T. (2007) Koncesionarke ne morejo nuditi vseh storitev, Vecer, 25. oktober 2007, p. 20.

Vuga, S. (1975a) Organizacija patronažne službe, Obzornik zdravstvene nege, 9(1), pp. 18-22.

Vuga, S. (1975b) Organizacija patronažne službe (nadaljevanje in konec). Obzornik zdravstvene nege, 9(2), pp. 103-111.

WHO - Regional Office for Europe (2000) Munich Declaration: Nurses and Midwives: a Force for Health, retrieved from: http://www.euro.who.int/_data/assets/pdf_file/0007/53854/E93016.pdf?ua=1 (8 July 2020).

WHO (2010) A framework, for community bealth nursing education (New Delhi: WHO - Regional Office for South East Asia).

WHO (2015) Nurses and Midwives: A Vital Resource for Health European compendium of good practices in nursing and midwifery towards Health 2020 goals, retrieved from: http://www.euro.who.int/_data/assets/pdf_file/0004/287356/Nurses-midwives-VitalResource-Health-Compendium.pdf (5 June 2020).

WHO (2010) A framework for community health nursing education (New Delhi: World Health Organization).

WHO (2017) Enhancing the role of community health nursing for universal health coverage (Human Resources for Health Observer Series, No. 18).

Wordsworth H., Moore R. \& Woodhause D. (2016) Parish Nursing: unique resource for community and district nurses, British Journal of Community Nursing, 21(2), pp. 66-74, doi: 10.12968/bjen.2016.21.2.66.

Worldometers (2020a) Croatia Population, retrieved from: https://www.worldometers.info/worldpopulation/croatia-population/ (2 July 2020).

Worldometers (2020b) Slovenia Population, retrieved from: https://www.worldometers.info/worldpopulation/slovenia-population/ (2 July 2020).

Worldometers (2020c) Countries in the world by population (2020), retrieved from: https://www.worldometers.info/world-population/population-by-country/ (2 July 2020).

Zavrl Džanovic, D. (2007) Dejavnost patronažnega varstva (Ljubljana: IVZ RS).

Zbornica zdravstvene in babiške nege Slovenije - Zveza strokovnih društev medicinskih sester, babic in zdravstvenih tehnikov Slovenije (2015) Pravilnik o izdaji mnenj za opravljanje zasebne zdravstvene dejavnosti na področju zdravstvene in babiške oskrbe in v postopku podelitve koncesije, sprejet 6.5.2015, retrieved from: https://www.zbornica-zveza.si/wp-content/uploads/2019/09/Pravilnik-oizdaji-mnenj-za-opravljanje-zasebne-zdr.-dej--na-podro\%C4\%8Dju-ZN-ali-BN-ter-oskrbe-inv-postopku-koncesije-06.05.2015.doc (2 July 2020).

Železnik, D., Horvat, M., Panikvar Žlahtič, K., Filej, B., Vidmar, I. et. al. (2011) Aktivnosti zdravstvene nege v patronažnem varstvu (Ljubljana: Zbornica zdravstvene in babiške nege Slovenije - Zveza strokovnih društev medicinskih sester, babic in zdravstvenih tehnikov Slovenije).

Županić, M. (2013) Organizacija, obrazovanje i kompetencije patronažnih medicinskih sestara, Hrvatski casopis za javno zdravstvo, 9(33), pp. 1-15.

\section{Legal Sources}

Kazenski zakonik RS (Criminal Code): Uradni list RS, no. 50/12 OCV, 6/16, 54/15, 38/16, 27/17, $23 / 20,91 / 20$. 
Kodeks etike v zdravstveni negi in oskrbi Slovenije (Code of ethics in nursing and care in Slovenia): Uradni list RS, no. 71/14.

Kodeks etike za babice Slovenije (Code of ethics for midwives of Slovenia): Uradni list RS, no. 71/14.

Plan i program mjera za djelatnost patronažne zdravstvene zaštite (Plan and program of measures for the activity of community bealth care): Narodne novine RH 126/06.

Pravila obveznega zdravstvenega zavarovanja (Rules on compulsory health insurance): Uradni list RS, no. $79 / 94,73 / 95,39 / 96,70 / 96,47 / 97,3 / 98,3 / 98,51 / 98,73 / 98,90 / 98,109 / 99,61 / 00,64 / 00$, $91 / 00,59 / 02,18 / 03,30 / 03,35 / 03,78 / 03,84 / 04,44 / 05,86 / 06,90 / 06,64 / 07,33 / 08,7 / 09$, $88 / 09,30 / 11,49 / 12,106 / 12,99 / 13,25 / 14,25 / 14,85 / 14,10 / 17,4 / 20$.

Pravilnik o pogojih za opravljanje zasebne zdravstvene dejavnosti (Rules on the requirements to be met by the persons engaged in private health activities): Uradni list RS, no. 24/92, 98/99, 64/17.

Pravilnik o pravilih in postopkih pri obravnavanju nasilja v družini pri izvajanju zdravstvene dejavnosti (Rules on procedures for dealing with domestic violence in the implementation of health activities): Uradni list RS, no. 38/11.

Pravilnik o vodenju registra zasebnih zdravstvenih delavcev: Uradni list RS, no. 24/92 98/99, 35/00.

Pravilnik za izvajanje preventivnega zdravstvenega varstva na primarni ravni (Rules on carrying out preventive health care at the primary level: Uradni list RS, no. 19/98, 47/98,26/00, 67/01, 33/02, $37 / 03,117 / 04,31 / 05,83 / 07.22 / 09,17 / 15,47 / 18,51 / 18,57 / 18$.

Resolucija o nacionalnem planu zdravstvenega varstva 2015 - 2025 - skupaj za družbo zdravja (Resolution on the National Health Care Plan 2016-2025 - ResNPZV 2015-2025): Uradni list RS, no. $25 / 16$.

Ustav Republike Hrvatske (Constitution of the Republic of Croatia - CRC): Narodne novine RH 56/90, 135/97, 08/98, 113/00, 124/00, 28/01, 41/01, 55/01, 76/10, 85/10, 05/14.

Ustava Republike Slovenije (Constitution of the Republic of Slovenia - CRS): Uradni list RS, no. 33I/91, 42/97, 66/00, 24/03, 69/04, 69/04, 69/04, 68/06, 47/13, 75/16.

Zakon o pacientovih pravicah (Patient Rights Act): Uradni list RS, no. 15/08; 55/17.

Zakon o preprečevanju nasilja v družini (Domestic Violence Act - DVA): Uradni list RS, no. 16/08, 68/16, $54 / 17$.

Zakon o sestrinstvu (Nursing Act- NA): Narodne novine RH 121/03, 117/08, 57/11.

Zakon o zdravstveni dejavnosti (Health Services Act - HSA): Uradni list RS, no. 23/05 (OCV1), 15/08, 23/08, 58/08, 77/08, 40/12, 14/13, 88/16, 64/17, 1/19, 73/19, 82/20.

Zakon o zdravstvenoj zaštiti (Health Care Act - HCA): Narodne RH 100/18, 125/19.

Zakonu o splošnem upravnem postopku (General Administrative Procedure Act - GAPA): Uradni list RS, no. $24 / 06-O C V, 105 / 06,126 / 07,65 / 08,8 / 10,82 / 13$. 
